A Theory of Contemporary Rhetoric 


\section{A Theory of Contemporary Rhetoric}

Richard Andrews

Routledge

New York 


\section{Contents}

List of figures

Acknowledgements

1 Introduction

2 Why rhetoric?

3 Rhetoric and English Studies

4 Rhetoric and composition

5 Rhetoric and power

6 Rhetoric and argumentation

7 Rhetoric and framing

8 Multilingual rhetoric

9 Rhetoric and poetics

10 Rhetoric and theatre

11 Rhetoric and multimodality

12 Rhetoric and the digital age

13 Rhetoric and education

14 The future of rhetoric

References 


\section{Acknowledgements}

No book on the communication arts can be the work of a single author, and I wish to acknowledge the voices and influences that have helped me to forge the present book. These include my Linguistics tutor at Oxford, Avril Bruton, whose weekly one-to-one sessions gave me an insight into the discipline that was so different, and yet so closely related to the literary studies that took up the rest of my week; Gunther Kress, whose generosity in recognizing the closeness of rhetoric to his own project of the exploration of multimodality and social semiotics has been a lasting inspiration; Paul Prior, whose work on re-thinking rhetoric has been a great influence; and Brian Street, Viv Ellis, Wayne Sawyer, Terry Locke, Terry Eagleton, Lilie Chouliaraki, Myrrh Domingo, Sally Mitchell, Mark Reid, Peter Medway, Michael Simons and Jude Fransman have all contributed in their different ways. I am grateful to Clifford Siskin and Leslie Santee Siskin of New York University for their generosity in involving me in The Re:Enlightenment Project; to David Kirkland of New York University for a public lecture at the Institute of Education London in May 2012 and conversations at the Institute of Contemporary Arts about rhythms of justice in hip hop and everyday textual practices; to Stephen Boyd Davis and Martina Margetts at the Royal College of Art, London, for organising the symposium, 'Representing Research Knowledge' in February 2012 and to my fellow presenters, Mine DogantanDack, Anna-Marjatta Milsom and Michael Hohl.

Colleagues at the Institute of Education continue to provide a climate for learning and intellectual exploration: Carey Jewitt, Andrew Burn in the fields of new technologies and media in relation to rhetoric; colleagues in English and Drama including John Yandell, Anton Franks (now The University of Nottingham), Gillian Anderson, Anne Turvey, Morlette Lindsay and Theo Bryer; those in English as a second and world language: John O'Regan, Siân Preece, Amos Paran, Catherine Wallace, John Gray, Lin Pan; support at senior levels especially from Chris Husbands, Michael Reiss and Mary Stiasny; colleagues at the Centre for Holocaust Education (Stuart Foster, Kay Andrews, Paul 
Sammons et al.); the Centre for Research and Evaluation in Muslim Education (Farid Panjwani, Idris Mears, Farah Ahmed, Ibrahim Lawson, Arshad Ali et al.); the International Centre for Intercultural Studies (Jagdish Gundara, Jack Peffers and Bob Ferguson); heads of department in Sue Rogers, Jacek Brant, Ann Phoenix, Marjorie Smith, David Gough; and the Centre for Research and Development in Catholic Education (Gerard Grace et al.); as well as colleagues at the Institute of Ismaili Studies, especially Fayyaz Vellani, for illuminating conversations about the relationship of discourse to faith, civilization and culture. I wish to thank particularly Julia Douetil for commissioning the sonnets on reading which appear in chapter 9. Colleagues at New York University's Steinhardt School have been an inspiration too: Mary Brabeck, Jim Fraser, Gordon Pradl, Joe Salvatore. I would also like to thank Manjit Benning, Sarah Smith, Rachel Shaw and Eve Wade who, through their diligence, hard work and unerring support have enabled me to work on this book during my tenure as Dean.

I am grateful to Tony Burgess, Jane Miller, Wayne Sawyer and the editors of the journal Changing English for permission to reproduce and re-work 'Moffett and rhetoric' in chapter 3 from volume 17:3, 251-260 (September 2010); and to Geoff Barton, Geoff Dean and Gary Snapper for permission to revise a short contribution to a special issue of EnglishDramaMedia on the future of English (June 2011), issue 20, p17.

An earlier version of chapter 8 on multilingualism and rhetoric was given as a paper at the $4^{\text {th }}$ Institute of Education-Beijing Normal University conference on education in Beijing, October 2012. It appeared in the conference papers: Papers on Equity and Quality in Education, Vol 3, 419-35. I wish to acknowledge Yan Fei, Pan Zimeng and Jin Tinghe, as well as the doctoral students named in the chapter, for allowing me to use their work.

Part of the chapter on framing was written in Cannes in 2012 at the summer home of Nicky Stanley, in Théoule-sur-Mer. Thanks go to her generosity for giving Dodi and me a few inspirational days there as a break from London. Chapters 5 and 10 were written in the Adirondack Mountains of upstate New York. 
Parts of chapters 6 and 13 appeared in the inaugural lecture series published by IOE Press. I am grateful to Jim Collins and IOE Press for permission to reprint extracts from that lecture.

Chapters 11 and 12 owe much to colleagues in the Centre for Multimodal Research at the Institute of Education: Gunther Kress, Carey Jewitt, Andrew Burn, Caroline Pelletier, Di Mavers, Jeff Bezemer, Myrrh Domingo, Sophia Diamantopoulou; and also to a seminar held at the Institute in December 2011, led by Caroline Haythornthwaite. In particular, I wish to acknowledge the generous input of Mary Hamilton, Lesley Gourlay, Rose Luckin, Mary Lea, Robin Goodfellow, David Barton and Chris Jones to helping me move to a notion of textual practices as a way forward for thinking about literacy/literacies. I have also had engaging discussions with Marianne Lagrange at Sage, London, on transformations in the world of publishing, and am grateful to her for her generosity and support.

The book draws on a number of research projects:

Arts Council/Photographers' Gallery/Artec grant for photography and digital arts in the curriculum, 1994-97

Arts Council grant to establish fellowship in 'Framing Visual and Verbal Experience', 1995

Arts Council grant for visual literacy research, May 1997

Arts Council/Institute for International Visual Arts grant, July 1997

Economic and Social Research Council, Research Seminars competition: Dialogue and Communities of Enquiry in Elearning in Higher Education: June 2004 [award reference: RES-451-26-0314] Economic and Social Research Council, Research Seminars competition: New forms of doctorate the influence of multimodality and e-learning on the nature and format of doctoral theses in Education and the social sciences. July 2008 [award reference: RES-451-26-0629]

I wish to thank Linda Bathgate, Naomi Silverman, Kayley Hoffman, Julia Sammaritano at Routledge New York for their willingness to support this theoretical excursion; and to Routledge for publishing its precursors: Argumentation in Higher Education (2009) and Reframing Literacy (2010). Thanks 
must also go to the publisher for the re-issue of Rebirth of Rhetoric: essays in language, culture and education in 2011.

\section{Introduction}

\section{Prelude 1}

\section{Berlin}

A city of memorials, a crossroads in time.

So much memory, it is impossible

to live in the present. You either re-live the past

or stare blankly into the future.

Blood, spirit, intellect are separate.

Obsession with the body.

Over-reliance on the rational.

A soul-less interest in the material.

Only in the Tiergarten,

away from the regimented suburbs and

the epic gateways, the Potsdamerplatz

and the Reichstag, are the pleasures

of bike tracks that intersect through the trees,

the distant sound of chamber music, birds in the trees, and the promise of coffee

and conversation at the very centre of Europe.

\section{Prelude 2}

I am sitting in a café on a street in Berlin.

First, the words. Every car is named - VW, Audi, Renault - and all have number plates which carry as many letters as numbers: country of origin within Europe, the European stars, regional identification. Shop signs are in German and English. With a mix of words, telephone numbers and invitations to go beyond for more information: Twitter, Facebook connections. There are banners announcing new shops and cafés about to open. On lampposts, there are road signs, political advertising (there must be an election soon). People pass by with clothes and bags that carry brand names. In the café, people are reading menus, books (novels, guides) newspapers and magazines.

In speech, there are groups of two, three and four in café. Some people, on their own, are talking into mobile phones. There is more than one language: a mix of languages sometimes. Some of the people walking by are on mobile phones too. 
Sounds: voices, laughter, car horns, ringtones, the sound of tyres on cobbles and on tarmac, the noise of the café kitchen, the rustle of papers.

Beyond words are clothes, car designs, road design, buildings and scaffolding indicating that a building is being restored.

And then, beyond these designed and made forms are people themselves: the human form in all its variety; dogs; birds hovering in the trees; the blue sky and clouds passing at a high level after a storm the previous day.

All these notes I am making with a biro on a waiter's notepad headed 'Rossler. Ihr GetrankeSpecialiist. Ihr Partner in Berlin und Brandenburg'. Then I transpose them into type on a Macbook Air in my hotel room, via a conventional (at least for the twentieth century and first part of the twentyfirst) QWERTY keyboard. I am conscious, every now and then, of Christopher Isherwood's 'I am a Camera', of Goodbye to Berlin, of the layered pre-history of voices and history and literature that precedes me and that informs my own perceptions and communications.

The time dimension is hardly touched on, otherwise.

This is the rhetoric of the street. It hardly begins to account for the interlinked rhetoric of communication in an ordinary street in Berlin. I have hardly engaged with the people or the street, except to order a cup of tea, drink it, pay the bill and leave. But even the bill is a record of a simple and also complex social interaction.

Rhetoric is ever present in these moments in a number of ways. It preserves the balance of human communication, reflects the schemata, is the schemata (in a speech act theory sense), enables the world to move on in a small way, combines highly rational behaviour with bodily needs (eating) and pleasures (drinking Darjeeling tea). Even the type of tea brings another part of the world, its production and economy, into the frame.

The frames are invisible, though we could trace their parameters. The occasion described above is that of the 'stop for tea' or refreshment. As it's specifically tea on this occasion, the ritual of the infusion, then the milk, then the infusion again (unusual for a Briton). The German/English encounter is managed adequately with minimal linguistic resources. Tea and coffee houses punctuate the streets of the city. There are enough people to fill the pavement tables of this particular café on a Tuesday afternoon in September. There are economics behind that: economics of time, resource, attention, choice and intention.

There is multimodality here, but also more than multimodality. Multimodality is ubiquitous: sound, printed words, spoken words, images, moving image, moving objects, gesture, the physics of the situation. There is also a range of media at play. The contact of the natural and physical worlds is a perpetual interplay. Symbols attach themselves to things or operating free of attachment, though always physically grounded.

Booth (2004) defines rhetoric as "the entire range of resources that human beings share for producing effects on one another; effects ethical, practical, emotional and intellectual [parentheses omitted]. It is the entire range of our use of 'signs' for communicating, effectively or sloppily, ethically or immorally" (pxi) However, part of the problem with this definition is its emphasis on 
'resources' and 'producing effects on one another'. The view is materialistic and rhetor-centred, and runs close to the edge of the definitions of rhetoric that invite pejorative readings. Such cornering of rhetoricis not Booth's intention, but the definition allows such a reading. My own emphasis is on the arts of discourse, thus giving the listener or reader or viewer - the receiver of the message - as much power as the rhetor (speaker, writer, producer). Rhetoric inhabits the space between communicators. And although Booth's attempt to refine definitions of actors in rhetoric via number of specific terms - listening rhetoric, rhetrickery, rheterology, rhetorologist - it is only the distinction between 'rhetor' and 'rheorician' that I think is helpful: the rhetor being the communicator, the rhetorician being the student of rhetoric. The other terms are modish and serve to make the field less unified, more subject to superficial critique, more like a quasi-science. Rhetorically speaking, they serve to weaken the defences of the theory in their very attempt to stake out new ground.

\section{The limitations of words}

Rhetoric, throughout its history, has been associated with words. Words, whether spoken or written, listened to or read, have been central to its development. They still are. The affordances of words are several: in speech, in most cases, they are a naturally occurring feature of human communication; they can be combined in countless combinations to make and communicate meaning; they are relatively economical in terms of production (unlike, say, film or still images); and, albeit that words differ from language to language, and even from dialect to dialect, they can be translated. Even with the 'turn to the visual', they have survived.

Judt (2010), in an essay on words, extols their virtues as a self-confessed, articulate lover of the mode. Regarding articulacy, he talks of it as being typically regarded as "an aggressive talent" (p149) but notes too that rhetorical flexibility "allows for a certain feigned closeness - conveying proximity while maintaining distance" (pp149-50). The essay notes that words may deceive, especially where form transcends content and that "sheer rhetorical facility, whatever its appeal, need not denote originality and depth" (p150) but that "inarticulacy surely suggests a shortcoming of thought" (ibid.). The core of the argument that good rhetoric revealed clear thought and expression is contained in the following:

For many centuries in the Western tradition, how well you expressed a position corresponded closely to the credibility of your argument. Rhetorical styles might vary from the spartan to the baroque, but style itself was never a matter of indifference. And 'style' was not just a well-turned sentence: poor expression belied poor thought. Confused words suggested confused ideas at best, dissimulation at worst. (p151)

The relationship between language and thought moves the debate to the philosophical domain and asks the question: what exactly is the relationship between thought and communication? This and related questions of what we might term the ontology or proto-genesis of rhetoric are not dealt with here, as they are more than adequately addressed in Vickers' In Defence of Rhetoric (1988) where he explores the Platonic-Aristotelian 'axis' and the continuing paradigm war between philosophy and rhetoric (ideas and the expression of ideas). It is not the case that such debates need not concern us here; rather, that our attention is focussed more pragmatically on the choreography of everyday, professional and academic discourse. The position of the present book is that the thesis and antithesis of the philosophy-rhetoric debate is a tired dialectic, and that the synthesis of the two positions allows us to focus more sharply on not only the inextricable nature of communication and 
thought, but on contemporary practices and the generation of new theory that will shed light on the patterns of these communicative practices.

Judt suffered from a variant of motor neuron disorder: one that deprived him of speech in his last years. But the relationship between clear communication and the articulation of thought continued to be a preoccupation. In reference to the debate between philosophy and rhetoric, his dependence on language was countered by a loss of control of words, and yet "they still form with impeccable discipline and unreduced range in the silence of my thoughts...Communication, performance, assertion: these are now my weakest assets. Translating being into thought, thought into words, and words into communication will soon be beyond me and I shall be confined to the rhetorical landscape of my inner reflections". This latter phrase has my italics (the others are Judt's). As testimony from an active mind in the grip of a loss of oral articulacy, it is a telling tribute to the power of rhetoric to map the nature and direction of thought - as if the outside, public channels and patterns of communication had lent shape to the formulation of thought. Stronger justification comes from the final paragraph of the essay: "No longer free to exercise it myself, I appreciate more than ever how vital communication is to the republic: not just the means by which we live together but part of what living together means. The wealth of words in which I was raised were [sic] a public space in their own right..." (p154).

It is partly Judt's inspiration that has led me to write this book in words only, eschewing the chance to produce a multimodal text. It is a decision that has consequences, some of them in limiting the scope of the book itself. But in other ways, it has forced me to try to articulate a theory of contemporary rhetoric, and to translate what I have wanted to 'say' in other modes into words.

The social and political raison d'être of rhetoric with regard to the maintenance of the republic for the puyblic ('the arts of social and political discourse') is reinforced by Judt's inspirational account. His emphasis on words is pre-multimodal, but the principles he outlines would apply to the multimodal as well as to the modes and sub-modes of verbal language: clarity of expression, sharp distinctions between words, a belief in rhetoric ("from the spartan to the baroque") as a means to effect communication. As was the case for Pound, the loss of clarity and distinction in language is a loss of clarity of thought and ultimately a loss to civilized life. Such responsibility of the part of all language users emphasizes the socio-political nature of Judt's vision: a republic in which the citizens are responsible for its quality of communication as well as for its mores, practices, infrastructures. Rhetoric's vision is similar: no individual exists outside the society which he or she inhabits. All have a responsibility to maintaining and developing the tools of communication that enable the society to operate. But words are not "all we have" (p154). There are others resources at our disposal, and these are set out more fully in chapter 11 on 'Rhetoric and multimodality'.

Indeed, the limitations and affordances of words need to be set out so that we are clear, from the start, that contemporary rhetoric is more than just a science or art of verbal language. Words - verbal language, whether it is spoken or written and in any language - are abstractions from the real, material, perceived world. The nouns and verbs, adjectives and adverbs are conceptual in that they offer an 'idea' of a range of possibilities in that category ('green' for example, covers a multitude of actualities). They can be combined into endless permutations, with the help of 'joining' words like definite and indefinite articles, prepositions, modal verbs and conjunctions, and modulated by tense to give a sense of a position in time (in some languages). The special characteristics of verbal 
language can be said to be its flexibility of use (charting degrees of abstraction); its ability to link concept to concept (for example in argumentation); its physicality (in voice); its potential for further abstraction (in written form); its potential subtlety; and its economic virtues (in normal circumstances, its relative 'low cost' as a resource in terms of production and reception). We should also note its propensity to modulate between the relative closeness to reality (descriptive, functional, manual-like uses) on the one hand, and metaphorical uses (on a macro-scale, in terms of degrees of fictionality and distance from the real world) on the other.

Conversely, what are the limitations of verbal language? We should be cautious here, as the affordances of language can be stretched and adapted to cover what other modes can more readily achieve (for example, a painting can be described in words). But we can say that words find it more difficult to chart space; to convey close physical feeling; to replicate touch; to communicate the direct, visceral nature of the seen, whether in photographic or painted or sculpted form, or simply in the perceived everyday world; and to convey movement. On first consideration, it would seem that words cannot match the senses or combinations of sensory experience in terms of their directness. The very abstracted nature of the word removes it at one stage from the immediate experience of everyday life. This general point holds true, even though we can all provide examples of where verbal language had a direct, physical, visceral effect on a situation or state of being: a declaration of love, a decision of 'guilty' or 'not guilty', the communication of failure or success. We also know from speech act theory that small words ("I do" in a marriage ceremony, for example), can have long-reaching personal, legal, spiritual, financial and public consequences. Nevertheless, we must accept that words alone do not constitute the entire communicational repertoire; and thus, they should not determine the scope of rhetoric. One of the main points of the present book is that we need a new theory of rhetoric because we have come to realize that words alone do not represent the full range of communicational resource available to us to make and convey meaning.

To reinforce the point about the limitations of words, consider the following scenarios. The direction of gaze in a crowded room, especially when two set of eyes meet, can communicate mutual interest and engagement. Hunched shoulders and a stooped physical posture in any number of sports can indicate the acceptance of defeat and the end of team effort. In a dance, the intricate positioning and re-positioning of bodies in relation to each other communicate an expressive, aesthetic kind of meaning to an audience that is not expressed in words. A music composition, or the sound of wind in the trees on a winter walk in a landscape devoid of verbal language both convey the structure of feeling and perception, and the read-off of meaning, that may be partially shaped by previous verbal encounters and repositories, but in their immediate state, do not call on words for their communicational power. A final example: the construction of a city, its architecture and its layout, although partially constructed with the help of words, depends also on mathematical calculations, spatial considerations and the sheer deployment of physical materials to 'make a statement'. Rhetoric, because it is the theory of the arts of discourse and communication in any mode (and, verbally, in any language) has the power not only to delineate and explore the internal workings of those separate fields and modes, but also to link them.

\section{Reflecting on the Berlin street}

If words themselves are inadequate to the task of providing an overarching, explanatory theory for the experiences on the Berlin street, and if, too, 'there is more than multimodality here', how could 
rhetoric describe and explain the phenomena? Further, how would a 'theory of contemporary rhetoric' begin to make sense of the scene?

One could circumvent and short-circuit the argument by saying that a description of the scene in words defeats itself from the start. There is more to the scene than words. But we have already accepted that words in themselves - and the whole repertoire of verbal language - can perform certain functions and not others. So we need to set a more demanding challenge. If multimodality acknowledges the range and combination of modes that are deployed in the production and experience of the scene, then why cannot multimodality provide a full account of the scene? The reason is that that multimodality, along with consideration of media, describes resources rather than operations and communicative lines. As Kress has acknowledged, multimodality does not constitute a theory (a patterned means of explaining how its constituent parts relate to each other and to the world), but rather material for a theory. Later in the book (chapters 11, 12) there is discussion of how social semiotics and rhetoric relate to each other in terms of providing such a theory.

In terms of media, one could say that a different mode and medium than words on a printed page might capture the completeness of the scene better than my minimal written notes in the café. To move quickly through the possibilities of soundscapes and still images (painting, photography) to fully-fledged film, how would this twentieth-century medium, film - incorporating, as it does, moving image, sound (including speech), written words and time/spatial characteristics - represent the actual scene? The limitations of film immediately present themselves as problems in representing the totality of the experience: first, film tends to use a limited number of cameras and thus a limited number of perspectives on the scene. It would need hundreds of cameras and the combinations of their recorded images to represent the scene in its totality. There would need to be extensive and judicious editing to frame the scene. At best, a kaleidoscopic and selective representation of the scene would be all that we could produce. There is no substitute for being in the actual scene, with smells, air quality, 'ambience', even though a limited individual perspective shares the same limitations of a filmic camera position with its ability to focus, change aperture etc. Second, film is subject to its own affordances and limitations - it is, by nature, a representative, selective take on a scene. Third, you need some kind of hardware viewer (the medium of smartphone, TV screen, computer screen or cinema screen) to receive the message.

Elsewhere (Andrews 2010), I have explored the contribution of framing to the understanding of how communication acts are made and received. But, again, framing does not constitute a theory per se. It is a mezzanine-level heuristic for working out how the resources of modes, via their various media, can be made to 'make sense' in a shared communicational space. Framing comes close to a theory because it draws on social and aesthetic considerations in order to define the parameters of the communicational encounter. But it remains an act (of framing) rather than an underpinning or overarching theory.

So, multimodality and framing are important constituents in helping us to make meaning and to communicate it. The third element that is needed in order to complete the repertoire of resources and heuristics is articulation. Articulation is a useful term in that it has two meanings: one is concerned with the clear expression of ideas, thoughts and feelings. This aspect of the term is usually associated with words. The other is to do with the joining of parts of an entity, as in the example of an articulated truck. We can apply both meanings of the terms to a range of different 
modes and their combination, in order to bring the term 'articulation' into line with the way we are moving: toward a comprehensive and multimodal theory of contemporary rhetoric.

Judt (2010) was particularly concerned with the sense of articulation in terms of clear expression of thought. To state clearly what is intended, without obfuscation or unnecessary decoration, hesitation, diversion or vagueness, is an art. The articulation can be of feelings as well as thoughts and ideas; or it can be more coolly to do with the accurate and valid expression of an idea - like the design of the London underground map. This latter example makes it clear that articulation is more than just the expression of thoughts or feelings by an individual; it can also apply to sound, visual art, film-making, or design work of any kind. The idea of articulation in this sense is central to rhetoric because of rhetoric's desire to find the most appropriate form for expression of an idea or need. The underlying principle here is one of clarity and functionality, of using the modes and media of expression to provide a valid and transparent account of that which is being expressed.

But articulation can also refer to how elements of communication are joined to each other, and for what purpose, in a composition of any kind. Examples are the joining of one piece of wood to another in a 'joint' - say, in the design and making of a chair; the linking of one idea to another in verbal argumentation; the conjunctions in a narrative; the way the frames of a comic strip or manga are joined (sometimes in straight sequence, sometimes with one large frame leading to smaller ones, or vice-versa); or the way different modes combine, e.g. a caption with a photograph, or the score of musical composition with verbal annotations and photographs. Each 'join' is a conscious compositional decision. Indeed, the joining together of parts into a new whole is at the heart of the nature of composition (as in collage, bricolage or patchwork where joining is most obviously evident). The chapter on rhetoric and composition attempts to explore such articulation in more detail.

So far we have mentioned multimodality, framing and articulation. There are at least three further considerations before the theory of contemporary rhetoric is complete in its outline form. These elements are outside the immediate frame of reference for composition, but help to determine the framing itself. They are the time-based dimension; contextual factors; and the question of digitisation.

Articulation has a part to play in the editing of a film. Conventionally, in pre-digital technology, each image of a film was captured on celluloid; each image was further articulated with another; and the overall articulation of the sequence, played at a particular speed, gave the impression of verisimilitude. Such time-based representation aimed to capture 'real-time', at least in part, in the effort to construct a work that was either fictional and/or documentary. Time, then, is a dimension of experience that rhetoric has to accommodate in order to build a theory that is adequate to needs, not least because digital media like smartphones and television or computer screens increasingly provide the means not only to read the moving image, but also to create it. From my static desk, composing text in words, the world of the moving image seems some way off; so too, to an artist composing a painting or sculpture, or to a designer working on a new object. But the dimension of time is never far away: the written text is not only composed over time, it is also read or received over time. Paintings are viewed in particular places and times. Time, if we see it from a western perspective, is continually moving, even if we have the impression that it can stand still. Rhetoric therefore has to embrace the dimension of time, most ostensibly in musical compositions, in films, 
in TV programmes, and in clips that are created for YouTube; but also as a fundamental principle of operation in the world in whichever mode and/or medium. The least that rhetoric can do is to create snapshots in time in order to create and analyze communicative phenomena; but it can do more - it can provide sub-categories of analysis and consideration like rhythm, pace, tempo that in themselves help to define and create communication.

Contextual factors have been written about much in the consideration of communication in the last thirty of forty years. They are partly a result of the significance of time and place to communication, but are also presented as a counterpoint to the overly inward and psychological theories of communication. The social dimension of communication requires that a consideration of context takes place. Who is speaking? To whom? About what? What is the motivation, purpose and intention? What are the social and political situations of the interlocutors? How might the communication be different if any of the above factors were changed? Context is particularly important to rhetoric because consideration of rhetorical dynamics starts not with the text, but with the social and political shaping of the text and the need for communication in a particular place and time. Contexts can range from immediate contexts (the people concerned, the time, the room in which they meet, the nature of the meeting and the formal conventions at play) to wider contexts (the current political situation, economic constraints, etc.). It is important to chart what the contextual factors are in any act of communication, and to map these factors in relation to each other so that a full picture of the nature of the communication is possible. Once the factors are understood, the communication can be shaped and adjusted accordingly.

Finally, in this catalogue of the constituent elements of contemporary rhetoric, what of digitisation? Digitisation has been over-egged in one sense. Particularly from the early 1990s onwards, the rise of digitisation has heralded grand claims about what it can do and how it can transform lives, societies and politics. In many senses, such changes have happened: we can transform 'information' from one mode to another, re-purposing it with ease. We can store huge amounts of information in small spaces, and examine in it from different perspectives and via different lenses. It has enabled electronic social networks of various kinds. Much has been written about the power and potential of digitisation. In rhetorical terms, its value is that it enables us to re-purpose and re-shape communication; it gives us a larger repertoire of media via which to communicate; and provides unlimited storage space. In chapter 12 , full consideration is given to the relationship of rhetoric and the digital.

\section{Towards a theory of contemporary rhetoric}

The record of sitting in a café on a street in Berlin is, in one sense, simple: it is the observed recording, initially on slips of paper borrowed from the waiter, of what is happening in and around the cafe in a given short period of time. In another sense, it is complex: the record hardly scratches the surface of what is going on in the interactions between a hundred or so people who moved through that street and around that café on that day in September 2011. Not only are there physical and spoken interactions; there are written rituals, like bills and receipts exchanged, as well as others who are recording on iPads, mobile phones or in notebooks. In addition, there is the material world of the street - buildings, cars, signs, baggage etc. - some of which is inscribed with words, icons, logos, images. Furthermore, there are the ambient sounds of the street: café music, the sound of radios from nearby apartments, music percolating from headphones of passers-by. 
In my initial notes, I mused that rhetoric is ever present in this scene; that the framing of the scene is virtually invisible; and that multimodality is present and ubiquitous, but insufficient to account for the wealth of communication that is taking place. The other elements of a rhetorical account articulation, digitisation, context and the time dimension - were not considered the time of initial recording and minimal reflection, but nevertheless play a part. Articulation is present in at least two of the senses of 'joining': first, in the segues between what we used to consider as genres or schemata (like the paying of a bill, with its own internal articulations) and the running continuo of experience (sitting in a café). This simple example will help to demonstrate that articulation operates to join one frame to another, one schemata to another. In this case, because the paying of a bill is part of the experience of sitting in a café, one frame is nestled within another. The line between the continuo of everyday experience, and the framed genre, is transgress-able, fuzzy, permeable. Articulations helps us to see the nature of those joins. Digitisation is evident in a number of ways, many invisible to the eye. Had I been writing and sketching on an iPad, it would have been more evident. Even so, the instantiation of sound as mentioned above; the wireless device via which the bill is paid at the table; the electronic navigating systems of cars that pass - all these and more are driven digitally, and transform information for particular purposes digitally. Context and time - in effect the immediate framing of space and the thirty minutes or so of sitting in the café - require some discussion. The context is not 'framed' tightly, though the café itself is (even though it spills out on to the street). The café is situated on a street, and views each way are extensive: one way to a major road junction, the other way into a denser part of the city. The context is, if we take the widest aperture possible, limitless - we have to provide framings of some kind in order to be able to make sense of the place and the experience. We can term that framing orientation. We can also move between foregrounded activity and phenomena - the tea cup, the table - and much further distant contextual elements, like Berlin, Germany, Europe. Moving between the foregrounded phenomena and those at more distance is a process of positioning, of multiple framing and articulation. Time is a less tangible, more elusive factor. Again, in one sense, it looks simple: I sat at the table on 14 September 2011 between 3.30pm and 4pm. If I had done the same thing half an hour later, or a day later, would the experience have been different? Actually, I did go back the next day to test exactly that (and because it was an excellent café). Much was the same. I do not think that the account I wrote on the first day would have been very much different from that on the second day. There were different people (even the waiters), different cars; but the same buildings, same street, same signs, same city. The weather was slightly different, and, of course, if I came back in a different season, or in a different year, there might be more significant and noticeable changes: the café might no longer be there, I would older or younger, and so on. The rhetoric of the scene would have changed.

We can thus say about the case of the Berlin café experience in relation to rhetoric that it helps us to define a spectrum of possibilities with regard to a theory of contemporary communication. At one end of the spectrum, we can use rhetoric to account for micro- and mezzo-social encounters, like the paying of a bill or a brief conversation with a stranger. There are formalities to observe with the bill: the customer requests the bill, orally or by gesture. The waiter calculates it and brings it to the table. There may be a pause. In due course, the customer pays the bill in one of a range of different ways, and either personally to the waiter, in his or her absence, or at a central till. The transaction is completed with a greeting, with thanks, or simply in silence. This example is close to a social schema, and the rhetoric of the situation is largely prescribed. In a brief conversation with a stranger, there 
are fewer 'rules'. One person initiates it by finding common ground for talk; the other reciprocates fully or not; the parameters of the conversation will be set by mutual agreement. There is a range of such speech, written and multimodal genres from the personal to the wider public sphere.

At the other end of the spectrum is the total experience of the period in the café in the Berlin street. By 'total' experience, I mean not only the total perceived and necessarily selective experience of one person and their observations, but the totality of the communicational networked scene in that place and at that time. The scene frames a multitude of social and communicational encounters, all framed, more widely, by the economic and political contexts that allow people to spend time in a café on a Wednesday afternoon in a European city. Within the chosen frame of the scene on the street, the communication could be charted. An exhaustive record of every conversation, every sign, every written transaction, every photograph, every physical movement - all in relation to the fixed phenomena of buildings and the moving objects of cars, bicycles etc. - could be attempted, and would be interesting. It would lend itself to multimodal discourse analysis. Behind that possibility are the instruments and dimensions of rhetoric (multimodality, articulation, framing, digitisation, context, time) that allow a somewhat broader analysis in terms of how the political interfaces with the social and communicational. The broadness does not mean that the tools of analysis and creation are more abstract; rather, that they can be deployed at macro-, mezzo- and micro-levels according to the purposes of the analysis. They are tools of process rather than of product. Their scaffolding is light: it can be constructed and taken down quickly.

Social network theory needs only be deployed if the relations in any field of analysis (any framed social encounter) are such that they affect the communication - because rhetoric's focus is on the communicational dimension. But social network theory meshes well with a rhetorical perspective. Its vocabulary of nodes and ties has application in considerations of where the clustering takes place in any social network, and where the strong and weak ties of communication are (and what the nature of communication along those connections is). In relation to the discussion above, what were termed macro-, mezzo- and micro-levels of communicational encounter can be mapped on to notions of whole networks - in this case, a section of a street in Berlin - or more limited perspectives, like the personal network of connections observed by the person in the café. If the limitations of scope of network analysis - and of the wider rhetorical picture - are bounded by the extent of data that can be collected, then analytics could help process a wider set of data that has been possible previously, and so the wider rhetorical perspective can be taken. The advantage of positioning rhetoric in relation to social network theory and analysis is principally that both can look at loosely bounded and hybrid social encounters as well as more conventional social patterns ('genres' as social action). While network analysis is more interested in the extent to which the structure and composition of ties affects social norms, rhetoric focuses on the agency of the actor/rhetor and his or her audiences, and the socio-political determinants of their communication. Rhetoric is both productive and analytical. There is more room for individual and group agency in rhetoric, as well as a longer tradition of adapting rhetoric to contemporary circumstances.

In order to explore the potential of rhetoric to account for the contemporary world, the book moves next to a historical account of why rhetoric is relevant, and how it comes to be in its present state. Chapter 2 explores this dimension in depth, arguing that classical rhetoric has had too strong a hold on twentieth century discourses, and that we need to fashion a new theory that is fit for purpose. The third chapter looks at rhetoric in relation to English studies, one of its traditional partners in 
epistemological boundary-making. In particular, the break-up of the field of English studies into first and second language learning, literary studies, film and media studies and so on, is seen in the light of the potential unifying theory of rhetoric - which also has the advantage of not being associated with only one language. Consideration of the lasting influence of the work of Moffett (1968) forms a large part of this chapter. Chapter 4 addresses the practical issue of the nature of composition in a theory of contemporary rhetoric, linking the putting together of ideas in the verbal arts to that in the visual, aural and spatial arts. The centrality of composition to a theory of rhetoric is re-affirmed, but not without a separation of the concepts of rhetoric and composition as currently conceived in many writing course sin higher education institutions. Chapter 5 concentrates on the political dimension of rhetoric, and specifically on issues of power that influence and inform communication. Notions of critical literacy and critical discourse theory are addressed, and the suggestion is made that 'critical' is an epithet that has outrun its usefulness (the same is argued in relation to 'literacy') - and that discourse and rhetoric are more useful, clearer and more technically precise terms. This chapter looks outward to media representation of politics itself to show how rhetoric operates in the public sphere.

The relationship between rhetoric and argumentation is discussed in chapter 6 . As argumentation is often foregrounded in rhetorical theory, the chapter asks why this is and what part argument and rhetoric play in contemporary democracies. This chapter is followed by one on framing - already discussed initially above - which is seen to have a crucial part to play in the creation of meaning as well as the definition of what is made, what is studied and what is analysed. The case for rhetoric's contribution to pedagogic theory is made here and again in chapter 13. Chapter 8 focuses on multilingual rhetoric, acknowledging that rhetoric does not confine itself to a single language, but can be applied to any language. The interest is largely on world languages (English, Mandarin, Spanish, Arabic) but languages spoken by fewer people are also considered. Language policy and globalization are issues that are addressed here, with an account of how rhetoric can unify the field of enquiry and practice. The next two chapters address the fictional and literary dimension of rhetoric: first, in looking at form as a rhetorical device in relation to poetics; and second in exploring the relationship between rhetoric and theatre.

The last part of the book is devoted to some of the key aspects of rhetoric that have been mentioned above: multimodality and digitisation. Chapter 11 addresses multimodality as a set of resources that are available for communication, and specifically looks at the case for backgrounding multimodality with social semiotic theory. Similarities and differences between social semiotic theory and rhetoric are discussed. Chapter 12 looks at the impact of the digital revolution on rhetoric, in particular at the transformative power of the digital to re-cast one form of information into another. These chapters are followed by two final chapters: one on rhetoric and education, which draws out the pedagogical implications of rhetoric; and one on the future of rhetoric, which casts a critical look at the nature of contemporary rhetoric and whether it can provide a sufficiently comprehensive theory of communication to be of real use to other disciplines and in practical, everyday situations. This final chapter, then, discusses rhetoric as one of a small number of key disciplines or meta-disciplines that, while not returning to the medieval trivium of grammar, logic and rhetoric, might provide a toolkit for making sense of contemporary communication as part of a wider field of knowledge production and use. 


\section{References and bibliography}

Abrahamson R.F. 1977. The Effects of Formal Grammar Instruction vs the Effects of Sentence Combining Instruction on Student Writing: A Collection of Evaluative Abstracts of Pertinent Research Documents. Houston, TX, USA: University of Houston.

Alexander, R.J. 2008. Towards dialogic teaching: rethinking classroom talk (4th edition), Thirsk: Dialogos.

Andrews, R. 1989 (ed.) Narrative and Argument. Buckingham: Open University Press.

Andrews, R. 1992. 'An exploration of narrative and argumentative structures in writing, with particular reference to the work of students in year 8', PhD thesis, University of Hull, July 1992.

Andrews, R. 2003. Research Questions. London: Continuum.

Andrews, R. 2007. 'Argument, critical thinking and the postgraduate dissertation' in Educational Review Vol. 59, No. 1, February 2007, pp. 1-18.

Andrews, R. 2008. The Case for a National Writing Project for Teachers. Reading: Centre for British Teachers (CfBT) Educational Trust.

Andrews, R. 2009. 'The importance of argument in education', Inaugural Professorial Lecture delivered at the Institute of Education, University of London, 12 May 2009

Andrews, R. 2010. Argumentation in Higher Education: improving practice through theory and research. New York: Routledge.

Andrews, R. (ed.) 1992/2012. Rebirth of Rhetoric: essays in language, culture and education. Abingdon: Routledge.

Andrews, R. 2012. 'Non-verbal argument'. Presentation at symposium, Representing Research Knowledge, London: Royal College of Art Research Methods Course (February 2012).

Andrews R., Torgerson C., Beverton S., Locke T., Low G., Robinson A., Zhu D. 2004a.The effect of grammar teaching (syntax) in English on 5 to 16 year olds' accuracy and quality in written composition. In: Research Evidence in Education Library. London: EPPI-Centre, Social Science Research Unit, Institute of Education.

Andrews R., Torgerson C., Beverton S., Freeman A., Locke T., Low G., Robinson A., Zhu D. 2004b. The effect of grammar teaching (sentence combining) in English on 5 to 16 year olds' accuracy and quality in written composition. In: Research Evidence in Education Library. London: EPPI-Centre, Social Science Research Unit, Institute of Education.

Andrews, R. and Haythornthwaite, C. (eds) 2007. The SAGE Handbook of E-learning Research. London: Sage 
Andrews, R., Borg, E., Boyd Davis, S., Domingo, M. \& England, J. (eds) 2012. The SAGE Handbook of Digital Dissertations and Theses. London: Sage.

Andrews, R. and Haythornthwaite, C. (eds) (forthcoming) The SAGE Handbook of E-learning Research. London: Sage, $2^{\text {nd }}$ edition.

Aristotle. 1996 Poetics. (trans. Malcolm Heath). London: Penguin Books.

Bain, A. 1871. English Composition and Rhetoric (facsimile ed., 1996, Scholars' Facsimiles \& Reprints, ISBN 9780820114972).

Bakhtin, M.M. 1982. The Dialogic Imagination: Four Essays. Austin, TX: University of Texas Press.

Bakhtin, M.M. 1987. Speech Genres and Other Late Essays. Austin, TX: University of Texas Press.

Ballif, M., Davis, D.D. and Mountford, R. 2008. Women's Ways of Making it in Rhetoric and Composition. New York: Routledge.

Banks, A.J. 2006. Race, Rhetoric, and Technology: searching for higher ground. Mahwah, NJ: Lawrence Erlbaum.

Barthes, R. (1970/1988) L'ancienne rhétorique: aide-mémoire (December 1970) in Communications, 16, 172-229. Reprinted in Barthes, R. (1988) The Semiotic Challenge. Oxford: Basil Blackwell, 11-94.

Barton, D. 2008. Literacy: an introduction to the ecology of written language. Oxford:

Wiley/Blackwell.

Battiscombe Gunn 1918. The Instruction of Ptah-Hotep and the Instruction of Keg'emni: the oldest books in the world

Bazerman, C. 1988. Shaping written knowledge: the genre and activity of the experimental article in science, Madison WI: The University of Wisconsin Press.

BBC 2012. 'Record numbers of international students' - accessed online at http://www.bbc.co.uk/news/business-12671198 on 5 August 2012 London: British Broadcasting Corporation.

BBC 2013. 'Preisident Obama praises US 'fiscal cliff' deal' - accessed online at http://www.bbc.co.uk/news/world-us-canada-20886182 on 2 January 2013 London: British Broadcasting Corporation.

Bergonzi, B. 1991. Exploding English: criticism, theory, culture. Oxford: Clarendon Press.

Black, P. and Muecke, S. 1992. 'A moment in fashion'. In Rebirth of rhetoric: essays in language, culture and education (ed. Andrews, R.), London: Routledge.

Blake, C. 2009. The African Origins of Rhetoric. New York: Routledge.

Booth, W.C. 1961. A Rhetoric of Fiction. Chicago: Chicago University Press. 
Brewis, G., Crook, D., Hardcastle, J. and Medway, P. (2013). Re-making English for the post-war world. Basingstoke: Palgrave Macmillan.

Brutt-Griffler, J. 2002. World English: a study of its development. Clevedon: Multilingual Matters.

Burke, K. 1950/1969. A Rhetoric of Motives. Berkeley CA: University of California Press.

Burke, K. 1966. Language as Symbolic Action: essays on life, literature and method. Berkeley: University of California Press.

Bergonzi, B. 1990. Exploding English: criticism, theory, culture. Oxford: Clarendon Press.

Booth, W.C. 1961. A Rhetoric of Fiction. Chicago: Chicago University Press.

Booth, W.C. 2004. The Rhetoric of Rhetoric: the quest for effective communication. Oxford: Blackwell.

Boyd Davis, S. 2012. 'Defending the thesis: the power of words'. Presentation at symposium, Representing Research Knowledge, London: Royal College of Art Research Methods Course (February 2012).

Bradbury, R. 1952. 'A sound of thunder' first published in Collier's Magazine and subsequently in The Golden Apples of the Sun. New York: Doubleday (1953).

Brewis, G., Crook, D., Hardcastle, J. and Medway, P. 2013. Re-making English in the Post-War World. Basingstoke: Palgrave Macmillan.

Brutt-Griffler, J. (2002) World English. Clevedon: Multilingual Matters.

Burke, K. 1950. A Rhetoric of Motives. New York: Prentice-Hall.

Burke, K. 1966. Language as Symbolic Action: essays on life, literature and method. Berkeley: University of California Press.

Combs W.E. 1976. Further effects of sentence-combining practice on writing ability. Research in the Teaching of English. 10: 137-149.

Combs W.E. 1977. Sentence-combining practice: do gains in judgments of writing 'quality' persist? Journal of Educational Research. 70: 318-321.

Corbett, E.J. 1965/1998. Classical Rhetoric for the Modern Student. New York: Oxford University Press ( $4^{\text {th }}$ edition, 1998).

Cremin, T. and Myhill, D. 2012. Writing Voices: creating communities of writers. Abingdon: Routledge.

Dixon, J. 1991. A schooling in English: critical episodes in the struggle to shape literary and cultural studies. Milton Keynes: Open University Press.

Dogantan-Dack, M. 2012. 'Capturing musical rehearsal and performance'. Presentation at symposium, Representing Research Knowledge, London: Royal College of Art Research Methods Course (February 2012). 
Duncan, S. 2012. Reading circles: novels and adult reading development. London: Continuum.

Eagleton, T. (1976) Marxism and Literary Criticism. Berkeley, CA: University of California Press

Eagleton, T. (1983) Literary Theory: an introduction. Oxford: Blackwell.

Eagleton, T. (2004) After Theory. London: Penguin.

Enos, T. (ed.) 2009. Encyclopedia of Rhetoric and Composition: communication from ancient times to the information age. New York: Routledge.

Fransman, J. and Andrews, R. (eds.) 2012. Special issue of Learning, Media and Technology on rhetoric and means of representation in the digital age. [details to follow]

Gee. J., Hull, G. and Lankshear, C. (1996) The New Work Order: behind the language of the new capitalism. Boulder, CO: Westview Press.

Goffman, E. 1986. Frame Analysis: an essay on the organization of experience. Hanover NH: Northeastern University Press, new edition.

Goldsworthy, A. 2004. Passage. London: Thames and Hudson.

Gourlay, L. 2011. Cyborg literacies. Paper given at New Media, New Literacies, New Learning seminar at the London Knowledge Lab, Institute of Education, 15 December 2011.

Green, B. 2006. English, literacy, rhetoric: changing the project?. English in Education, 40:1, 7-19.

Grierson, H.J.C. 1945. Rhetoric and English Composition. Edinburgh: Oliver and Boyd ( $2^{\text {nd }}$ edition, revised).

Habermas, J. 1984. The theory of communicative action: vol 1 Reason and the rationalization of society, (translated by Thomas McCarthy) (originally published in 1981 by Suhrkamp Verlag, Frankfurt), Boston MA: Beacon Press and London: Heinemann.

Hoggart, R. (1957) The Uses of Literacy. London: Chatto and Windus.

Hohl, M. 2012. 'Grounded theory in the evaluation of an immersive art work.' Presentation at symposium, Representing Research Knowledge, London: Royal College of Art Research Methods Course (February 2012).

Hunter, I. 1997. After English: towards a less critical literacy. In S. Muspratt, A. Luke, and P. Freebody (eds) Constructing Critical Literacies: teaching and learning textual practice. Cresskill NJ: Hampton Press, 315-34.

Iser, W. 1980. The Act of Reading: A Theory of Aesthetic Response. Baltimore, MD: Johns Hopkins University Press.

Jewitt, C. 2011. 'Technology and reception as multimodal remaking' in Multimodality in Practice: Investigating Theory-in-Practice-through-Methodology, edited by Sigrid Norris. London: Routledge 98-112. 
Joseph, M. 2002. The Trivium: logic, grammar and rhetoric - understanding the nature and function of language. Philadelphia: Paul Dry Books, Inc.

Judt, T. (2010) The Memory Chalet. London: William Heinemann/Vintage.

Kahane, H. and Cavender, N. 1997. Logic and Contemporary Rhetoric the use of reason in everyday life. Florence, KY: Wadsworth (now part of Cengage)

Kaplan, A.M. and Haenlein, M. 2010. 'Users of the world unite! The challenges and opportunities of social media' Business Horizons, 53:1, 61.

Kaufman, M. 2001. The Laramie project. New York: Vintage Books.

Kinneavy, T. 1971. A Theory of Discourse Englewood Cliffs, NJ: Prentice-Hall.

Kirkland, D. 2012. 'Rhythms of justice: hip hop in the development of literacy'. Public lecture, Faculty of Children and Learning, Institute of Education, University of London, May 2012.

Kress, G. 2003. Literacy in the New Media Age. London: Routledge.

Kress, G. 2005. Communication now and in the future, English 21, accessed at: http:www.qca.org.uk/i2292.html, February 26, 2010

Kress, G. 2009. 'Assessment in the Perspective of a Social Semiotic Theory of Multimodal Teaching and Learning' in C.M. Wyatt-Smith, J.J. Cumming (eds.), Educational Assessment in the 21st Century, Dordrecht: Springer.

Kress, G. 2010. Multimodality: a social semiotic approach to contemporary communication. Abingdon: Routledge.

Kress, G. and van Leeuwen, T. 2001. Multimodal discourse: the modes and media of contemporary communication, London: Edward Arnold.

Lanchester, J. 2013. 'Let's call it failure'. London Review of Books, Volume 35, Number 1, 3 January 2013, 3-6.

Lanham, R. 1993. The Electronic Word: democracy, technology and the arts, Chicago: Chicago University Press.

Lanham, R. 2006. The Economics of Attention: style and substance in the age of information. Chicago: University of Chicago Press.

Larson, M., Britt, M.A., \& Larson, A. 2004. 'Disfluencies in comprehending argumentative texts'. Reading Psychology, 25:3, 205-24.

Lawlor, J. 1980. Improving Student Writing through Sentence Combining: A Literature Review. Technical Note. Los Alamitos, CA, USA: Southwest Regional Laboratory for Educational Research and Development. ERIC document number ED 192356.

Link, P. 2009. 'China's Charter 08', New York Review of Books, January 15, 2009, 54-6. 
Lipman, M. 1976. Philosophy for children, Oxford: Basil Blackwell.

McEwan, I. 2012. Sweet tooth. London: Jonathan Cape.

Milsom, A-M. 2012. 'Representing "thick" translation'. Presentation at symposium, Representing Research Knowledge, London: Royal College of Art Research Methods Course (February 2012).

Mitchell, W.J.T. 1986. Iconology, Chicago: Chicago University Press.

Moffett, J. 1968/1983. Teaching the Universe of Discourse. Boston: Houghton Mifflin Company (1983 re-issue).

Moffett, J. and Wagner, B.J. 1968/1991. A Student-Centered Language Arts Curriculum Grades K-12: a handbook for teachers. Portsmouth NH: Boynton-Cook.

Morgan, E. (1973) From Glasgow to Saturn. Cheadle: Carcanet Press.

Ney J.W. 1980. A short history of sentence combining: its limitations and use. English Education 11: 169-177.

On, Lee Wing 1996. 'The cultural context for Chinese learners: conceptions of learning in the Confucian tradition' in Watkins and Biggs, 1996, 25-41.

Orwell, G. 1949. Nineteen Eighty-four. New York: Harcourt, Brace \& World.

Pavel, T. 1986. Fictional Worlds. Cambridge MA: Harvard University Press.

Perelman, C. (1982) The Realm of Rhetoric. Notre Dame, Indiana: University of Notre Dame Press.

Pinter, H. 1988. Mountain language. London: The Times Literary Supplement, 7-13 October 1988.

Porrovecchio, M. (ed.) 2010. Reengaging the Prospects of Rhetoric: current conversations and contemporary challenges. New York: Routledge.

Preminger, A., Warnke, F.J. and Hardison, O.B. 1965/1986. The Princeton Handbook of Poetic Terms. Princeton: Princeton University Press.

Preminger, A., Brogan, T. and Warnke, F.J. 1974/1993. The New Princeton Encyclopedia of Poetry and Poetics. Princeton: Princeton University Press.

Prior. P. et al. 2013. Remediating the canons in Kairos 11.3. Accessed via

http://kairos.technorhetoric.net/11.3/binder.html?topoi/prior-et-al/index.html on 6 January 2013.

Ratcliffe, K. (2012) Critical Literacies. London: Longman.

Rogoff, B. 1992. Apprenticeship in Thinking. New York: Oxford University Press.

Said, E. (1978) Orientalism. New York: Vintage.

Sliding Doors (1998) British-American romantic comedy-drama film written and directed by Peter Howitt, starring Gwyneth Paltrow and John Hannah 
Stewart M.F .1979. Sentence-combining: its past, present and future. English Quarterly 12: 21-36.

Stotsky S.L. 1975. Sentence-combining as a curricular activity: its effect on written language development and reading comprehension. Research in the Teaching of English 9: 30-71.

Street, B. (1984) Literacy in Theory and Practice. Cambridge: Cambridge University Press.

Street, B. (ed.) (1993) Cross-cultural Approaches to Literacy. Cambridge: Cambridge University Press.

Street, B. (1995) Social Literacies. Harlow: Longman.

Street, B. 2001. Literacy and Development. London: RoutledgeFalmer.

Street, B. and Lefstein, A. 2008. Literacy. Abingdon: Routledge.

Saussure, F. de. 1922/1983. Course in General Linguistics. Eds. Charles Bally and Albert Sechehaye. trans. Roy Harris. La Salle, Illinois: Open Court.

Strickland, S. 2008. Engladesh. Final Masters presentation, London: City University. Available at: www.engladesh.com and www.samstrickland.com

Tindale, C. 2004. Rhetorical Argumentation: principles of theory and practice. London/Thousands Oaks CA: Sage.

Toulmin, S. 1958/2003. The uses of argument, Cambridge: Cambridge University Press.

Troyan, S.D. 2004. 'Unwritten between the lines: the unspoken history of rhetoric' in S.D. Troyan, Medieval Rhetoric: a casebook. New York: Routledge, 217-45.

Tufte, E. $[x x x x]$ The visual presentation of data etc. (fort ch 14)

Vickers, B. 1989. In Defence of Rhetoric. Oxford: Clarendon Press.

Vygotsky, L. 1991. Genesis of the higher mental functions. In Light, P. et al. (1991) Learning to think. London: Routledge, 32-41 (originally appearing as 'Development of the higher mental functions', 1930-1).

Watkins, D. And Biggs, J. (eds) 1996. The Chinese learner: cultural, psychological and contextual influences Hong Kong: University of Hong Kong, Comparative Education Research Centre.

Wellman, B. 2012. Networked: the new social operating system. Cambridge MA: MIT Press.

White R.S. and Karl H. 1980. Reading, writing and sentence combining: the track record. Reading Improvement 17: 226-232.

Williams, R. 1977. Marxism and Literature. Oxford: Oxford University Press. 
